\title{
"Employee engagement and best practices of internal public relations to harvest job performance in organizations"
}

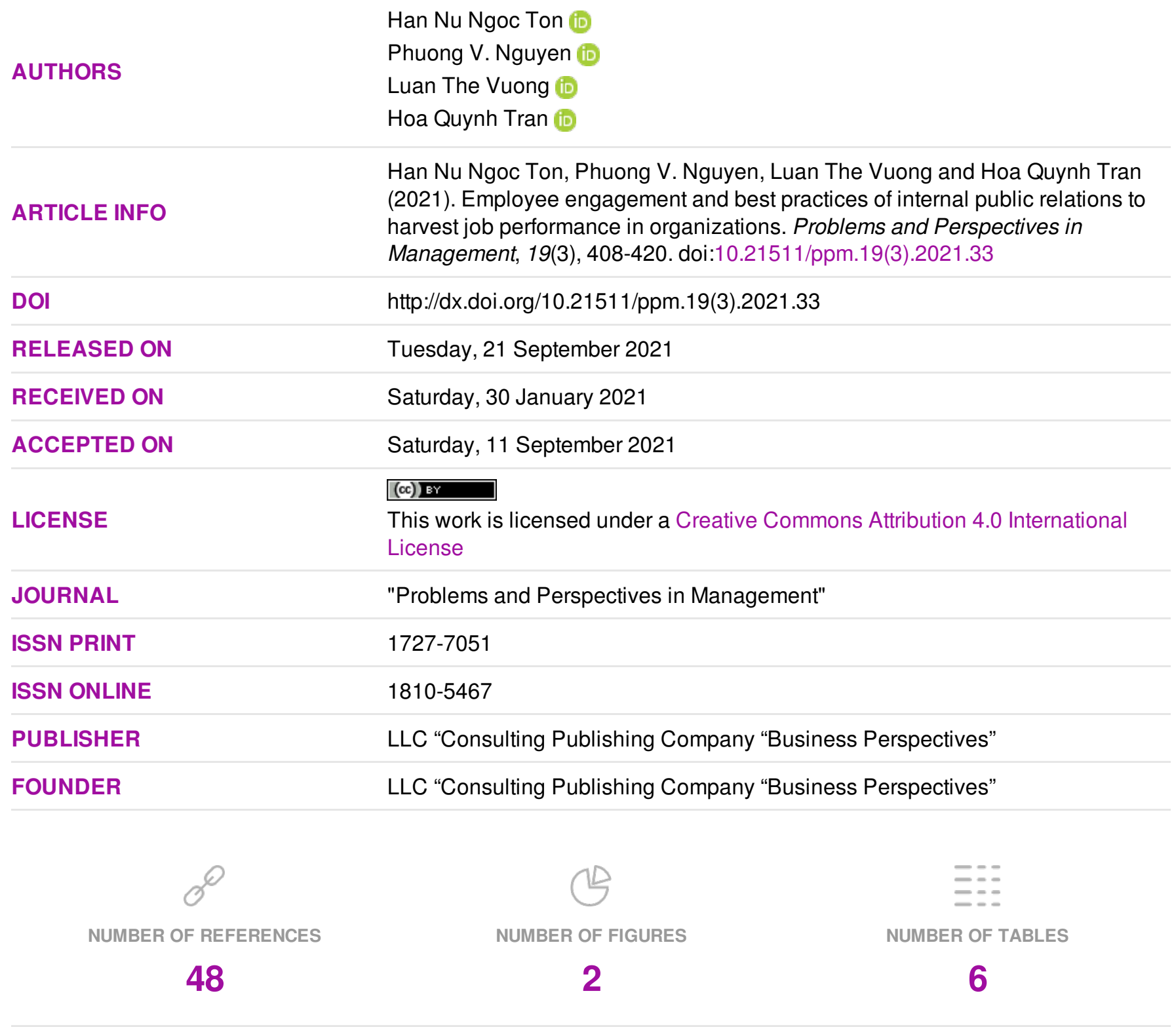

(c) The author(s) 2021. This publication is an open access article. 


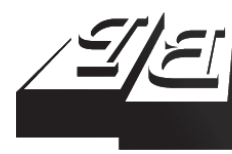

\section{BUSINESS PERSPECTIVES}

(O)

LLC "CPC "Business Perspectives" Hryhorii Skovoroda lane, 10, Sumy, 40022, Ukraine www.businessperspectives.org
Received on: $30^{\text {th }}$ of January, 2021 Accepted on: $11^{\text {th }}$ of September, 2021 Published on: $21^{\text {st }}$ of September, 2021

( ) Han Nu Ngoc Ton, Phuong V. Nguyen, Luan The Vuong, Hoa Quynh Tran, 2021

Han Nu Ngoc Ton, Ph.D., Lecturer, School of Business, International University, Vietnam National University, Vietnam.

Phuong V. Nguyen, Ph.D., Associate Professor, Center for Public Administration, Internationa University, Vietnam National University, Vietnam. (Corresponding author)

Luan The Vuong, Graduate Student, International University, Vietnam National University, Vietnam.

Hoa Quynh Tran, Graduate Student, University of Economics, Vietnam.
Han Nu Ngoc Ton (Vietnam), Phuong V. Nguyen (Vietnam), Luan The Vuong (Vietnam), Hoa Quynh Tran (Vietnam)

\section{EMPLOYEE ENGAGEMENT AND BEST PRACTICES OF INTERNAL PUBLIC RELATIONS TO HARVEST JOB PERFORMANCE IN ORGANIZATIONS}

\begin{abstract}
Internal public relations are used to control the relationship between the organization and its employees. The paper explored whether and how internal public relations stimulate employees' life satisfaction and job performance. The conceptual framework was built to link internal social media, perceived organizational transparency (POT), organizational identification, employee engagement, life satisfaction, and job performance. Using the hierarchical component model with employee engagement measured by job engagement and organizational engagement is a nascent point from this study. A mass survey was distributed to employees working in the aviation in dustry in southern Vietnam. Partial least squares structural equation modeling was used to analyze primary data from 193 valid respondents. It reveals that POT, in ternal social media, and organizational identification significantly positively impact employee engagement. It shows that employee engagement has significantly positive impacts on life satisfaction and job performance. It indicates that both organizational identification and POT are partial mediators intervening in the strong relationship between employee engagement and internal social media. It also indicates that life satisfaction is a partial mediator intervening the positive linkage between employee engagement and job performance. Practical implications and theoretical contributions were suggested for using internal public relations to enhance employees' life satisfaction, and job performance.
\end{abstract}

\section{Keywords}

internal public relations, employee engagement, internal social media, job performance

\section{JEL Classification J24, J53, J58}

\section{INTRODUCTION}

Organizational success comes from the ideal relationship between management and employees. Internal public relations explain how these two different groups can be combined in appropriate and effective ways to achieve organizational goals and objectives (Kennan \& Hazleton, 2006). Previous studies explored how internal social media (ISM) can enhance employee engagement in qualitative approaches (Ewing et al., 2019; Parry \& Solidoro, 2013). To enhance internal public relations at the workplace, Men et al. (2020) introduced the usage of ISM in two primary forms. First, organization-designed ISM enhances social interactions (i.e., information sharing and collaboration). Second, public social networking is frequently used, such as Facebook and Twitter. Internal public relations recorded internal social media's essential role in driving employee engagement by building organizational transparency and images.

The role of employee engagement in creating a sustainable working environment has become an essential issue in human resource man- 
agement. Leiter and Bakker (2010) define employee engagement as the connection between employees and their employers and describe it as a driver of job performance at both the individual and corporate levels. Social exchange theory was proposed to explain antecedents and outcomes of employee engagement that task performance and extra-role performance are fruitful benefits (Saks, 2006, 2019). The job demands-resource model has been used to describe the triangular relationship among work engagement, life satisfaction, and job performance (Demerouti \& Cropanzano, 2010; Mache et al., 2014). Conservation of resources theory also bolsters a simple causal connection between work engagement and job performance (Halbesleben, 2010).

The most important public from the perspective of employees and public relations is management, but the essential public is employees. Finally, developing and then explaining a productive relationship to the external public is critical to achieving objectives such as attracting investors, customers, and new workers (Kennan \& Hazleton, 2006). However, empirical results of the relationships between internal public relations and other positive employee perspectives such as life satisfaction and job performance in an emerging market are still limited. Therefore, this study aims at exploring employee engagement with two main dimensions (e.g., job engagement and organizational engagement), and investigating the sequencing relationships among ISM, employee engagement, and job performance alongside other intervening variables (e.g., perceived organizational transparency (POT), organizational identification, and life satisfaction). Indeed, employees can perceive organizational transparency and images through ISM. This process can generate an engaged state from employees toward their jobs and the organization. Going beyond this, the organization can benefit from the job performance and life satisfaction of its employees.

This study contributes to employee engagement research in two substantial ways. It fulfills Saks' (2019) research gap by exploring employee engagement with two abstract dimensions (e.g., job engagement and organization engagement) in a structural framework. This study is the first to build the integrative model reflecting the mechanism of how internal public relations lead to life satisfaction and improve job performance among employees working in the aviation industry in Vietnam.

\section{LITERATURE REVIEW}

Since the 1990s, "employee engagement" has gradually appeared in academia and business practice (Schaufeli \& Bakker, 2010). Saks (2006) established two types of employee engagement and described their antecedents and consequences using social exchange theory. Kahn (1990) described individual engagement as creating occupational roles among employees and how individuals perform their physical, cognitive, and emotional roles. Rich et al. (2010) mentioned three aspects of job engagement (e.g., "physical engagement", "emotional engagement", and "cognitive engagement") and proved job performance as a consequence of job engagement. Organizational engagement reflects employees' desire to belong to their organization and indicates employees' willingness to work for the general benefit of their organization (Juhdi et al., 2013).
Job performance is defined as "the aggregated value to an organization of the set of behaviors that an employee contributes both directly and indirectly to organizational goals" (Rich et al., 2010, p. 619). Christian et al. (2011) summarized two aspects of job performance from previous studies. For the first dimension, task performance/ in-role performance represents how individuals perform their occupational positions (Borman \& Motowidlo, 1997). The second dimension, contextual performance/extra-role performance, represents an employee's propensity to behave consistently with their organization's psychological and social context (Borman \& Motowidlo, 1993).

Social exchange theory is a well-known paradigm for explaining organizational behavior in various disciplines (e.g., management, anthropology, social psychology) (Cropanzano et al., 2017). Social exchange theory explains the reciprocal process according to which employee rewards and incen- 
tives serve as a critical motivator when eliciting fruitful employee outcomes (e.g., job performance, loyalty, trust, mutual commitment, engagement, rules of exchange). For instance, employees believe it is their responsibility to demonstrate good job performance when receiving economic and socio-emotional resources (Cropanzano \& Mitchell, 2005). Social exchange theory was used as underpinning theory to explore employee engagement in terms of antecedents and consequences and mediator roles intervening in different causal relationships (Saks, 2006).

Various studies used the job demands-resources model to explains the comprehensive relationships among individual and organizational resources, work engagement, and job performance. In other words, different aspects of the working environment can generate high levels of job performance through work engagement (Demerouti et al., 2001; Demerouti \& Cropanzano, 2010; Xanthopoulou et al., 2008; Xanthopoulou et al., 2009).

Conservation of resources theory has been used to describe individual strategies for investing resources to achieve better pay-offs. In other words, conservation of resources theory can explain causal relationships between employee engagement and its consequences, namely organizational commitment, performance, and turnover intention. Halbesleben (2010) found that work engagement was a significant positive force in generating organizational commitment.

Freberg (2019) emphasized the intimate relationship between social media and public relations with four novel opportunities: engagement, knowledge sharing, usage of strategic storytelling, and lifting the barriers between the organization and its vital public. According to Kennan and Hazleton (2006), internal public relations deal with the mutual interaction between the organization and its employees. Organizational success can be achieved when it remains the ability to link between management and employees. Best management practices lie not in superior knowledge and planning/method. Employees have selected to make cooperation in what they perceived to be a reasonable and justifiable managerial vision. The organization seeks to convince its employees that cooperation is in their best interest. Success at in- ternal public relations lies in the effective management of group relationships to create a favorable environment, in which task accomplishment is encouraged.

Men et al. (2020) reviewed various studies to introduce the structural framework explaining internal public relations within the organization. ISM was used to generate employee engagement through POT and organization identification. In the late 2010s, enterprises enormously invested in ISM, which took two basic forms: enterprise social media to boost intra-organizational social interactions and social networking in public settings. For instance, Starbucks has used Twitter to inspire employees and promote work-life balance (Ewing et al., 2019; Leonardi et al., 2013; Taurasi, 2015; Wang \& Kobsa, 2009; Weber \& Shi, 2016). Indeed, these platforms enable their employees to share organizational messages and act as corporate ambassadors. Organizational reputation and employee recruitment can be improved from the process of ISM. Social capital is created and strengthened in communications via ISM, and new ties are made among employees (Weber \& Shi, 2016). Knowledge sharing, collaboration, and innovation occur on ISM, enabling firms to gain higher effectiveness and efficiency in employee performance. Employee engagement and job performance are fruitful benefits from internal public relations (Leonardi et al., 2013).

Several studies explored three typologies of ISM use: consuming, conversing, and contributing (Men et al., 2020; Men \& Tsai, 2013; Muntinga et al., 2011). Consuming means that employers consume the information available from posts on ISM; for example, they can view and have their thoughts about this information. Conversing refers to employee engagement with organization-specific private groups on social media. Contributing occurs when employees create content by sharing, commenting, and tagging in order to induce more interaction by exchanging ideas and raising other issues related to an initial topic.

Berggren and Bernshteyn (2007) defined organizational transparency as open discussion and employee involvement to understand common goals and objectives. Transparent organizations actively create action plans. Employees can com- 
prehend the current situation and the organization's possible scenarios, especially concerning the decision-making processes; they can participate in along with leaders. Therefore, individuals can make more contributions to and have a greater effect on the success of an organization. McCorkindale and Distaso (2014) found that transparency was highly relevant to open and honest communication as well as mutual trust in sharing.

ISM enables people to connect and enact transparency in communication (Leonardi et al., 2013). Trust and credibility are generated through the process of transparent organizational communication; organizational transparency then potentially fosters employee engagement (Jiang \& Men, 2017; Linhart, 2011; Rawlins, 2008). Organizational identification refers to the set of connections built by an organization and its employees over common values of understanding and attributes (Men et al., 2020). Openness can foster a sharing attitude among employees (Smidts et al., 2001). If they understand the common goals they help achieve, employees will feel more associated with their organization, thus enhancing their pride and ownership (Ashforth et al., 2008; Smidts et al., 2001). In fact, these outcomes are essential components of employee engagement. Employee engagement helps employees feel associated with a company's values and vision and increases their energy to expend extra effort. Hence, organizational identification can enhance employee engagement (Men et al., 2020; Ewing et al., 2019).

The comprehensive relationships between ISM and employee engagement were proven in two qualitative studies (Ewing et al., 2019; Parry \& Solidoro, 2013). The best practice of ISM is to create employee engagement through various communication activities, such as information transfer, information selection, leadership, and listening. Organizational culture and managerial behaviors are emphasized in such practices; in particular, leaders should collaborate and benefit from social conventions.

Work engagement significantly influences two types of job performance, including task performance and contextual performance. Engagement helps to generate organizational effectiveness and reinforce competitive advantage. An engaged employee is supposed to have more efficient and ef- fective job performance and a friendly social environment that involves teamwork, a helping spirit, and critical discretionary behaviors. Moreover, another study found employee engagement plays an essential mediating role in connecting working environments and employee performance (Anitha, 2014).

The causal relationship between work engagement and life satisfaction has been explained using the job demands-resources model (Mache et al., 2014). Life satisfaction significantly impacted job performance (Talukder et al., 2018).

Internal public relations were explored through the comprehensive model and the interrelationships among ISM, POT, organizational identification, and employee engagement (Men et al., 2020). Antecedents and consequences of employee engagement were summarized in the critical works of Saks (2006) and Saks (2019); job satisfaction was one crucial consequence. This study would create the hybrid model linking the block of internal public relations to life satisfaction and job performance. It can explain how internal public relations generate life satisfaction and job performance among employees.

Previous studies explored employee engagement in different ways. Job engagement/work engagement and organizational engagement were measured in unidimensional constructs separately in the measurement model (Saks, 2006, 2019). Some studies blurred the distinction between job/work and organizational engagement and combined these two aspects into one single measure of employee engagement (Men et al., 2020). Thus, to fill the research gap, this study would build the hierarchical component model with employee engagement as multidimensional constructs (e.g., employee engagement is measured by job engagement and organizational engagement).

The study aims to explore how internal public relations enhance life satisfaction and improve job performance among employees working in the aviation industry in Vietnam. Specifically, the study examines the causal relationships among ISM, POT, organizational identification, employee engagement, life satisfaction, and job performance (Figure 1). 


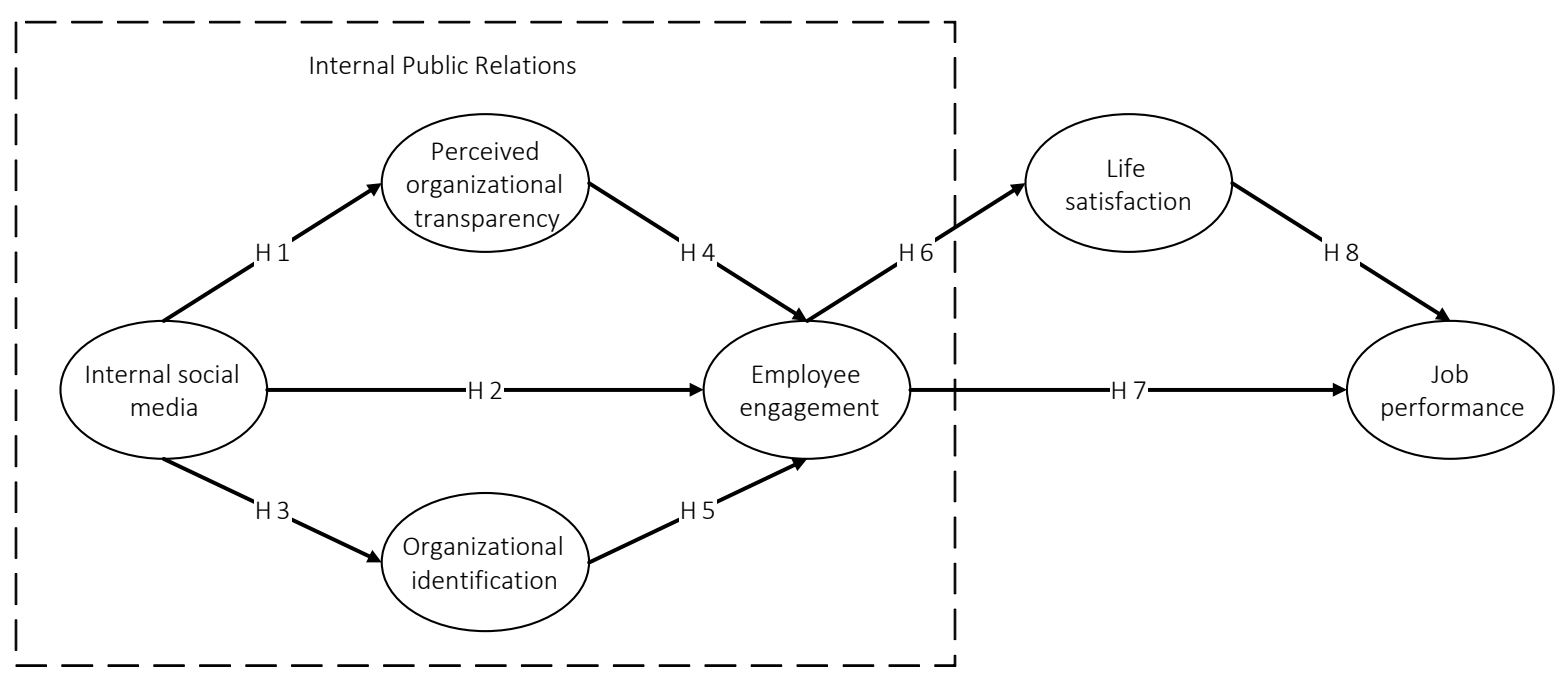

Figure 1. Conceptual framework

The study proposes the following hypotheses:

H1: ISM has a significantly positive impact on POT.

H2: ISM has a significantly positive impact on employee engagement.

H3: ISM has a significantly positive impact on organizational identification.

H4: $\quad$ POT has a significantly positive impact on employee engagement.

H5: Organizational identification has a significantly positive impact on employee engagement.

H6: Employee engagement has a significantly positive impact on life satisfaction.

H7: Employee engagement has a significantly positive impact on job performance.

H8: Life satisfaction has a significantly positive impact on job performance.

\section{METHODOLOGY}

The measurement scale was developed from previous studies. Five items of ISM by Muntinga et al. (2011) were used. An example of one item is "Rating, joining, engaging, and commenting products and/or brand-related on social network sites such as blogs, fan pages, YouTube and so forth." POT was measured by seven items adapted from Rawlins (2008), in which the sample item is: "Provides information that is accurate, easy to understand, complete, relevant, reliable, and so forth". Organizational identification was measured by six items adapted from Miller et al. (2000). The sample item is "I talk up this organization to my friends as a great company to work for". Employee engagement, a second-order construct, was measured based on two latent constructs, including job engagement and organizational engagement, by using 16 items adopted from Saks (2006) and He et al. (2014), in which the sample items are: "I devote a lot of energy to my job" and "Being a member of this organization is exhilarating for me". Five items of life satisfaction by Talukder et al. (2018) were used. An example of one item is "I am satisfied with my life". Five items of job performance by Talukder et al. (2018) were used. An example of one item is "I adequately complete assigned duties". A total of 44 items were used to measure the constructs and test the hypotheses visualized in Figure 1. The survey had two parts: demographic information about respondents and a questionnaire answered on a five-point Likert scale. The main survey was conducted in the Vietnamese language translated from the English version and adjusted with the support of 12 experts working in the Vietnamese aviation industry.

The mass survey was conducted in the second quarter of 2020 among employees working in the 
aviation industry in South Vietnam, specifically focusing on three companies (Vietnam Airline Company, Vietjet Air, and Tan Son Nhat Airport).

Partial least squares structural equation modeling (PLS-SEM) was conducted by using the SmartPLS software version 3.0 to test the hypotheses shown in Figure 1. PLS-SEM is a form of distribution-free multivariate data analysis used for small sample sizes with high confidence and accuracy. Bootstrapping techniques were used for resampling rather than distribution assumptions.

The conceptual framework was built in the form of a hierarchical component model. The second-order construct of employee engagement was established by two first-order constructs, namely job engagement, and organizational engagement. Reflectivereflective specification of higher-order constructs was applied to build the hierarchical component model. Higher-order constructs support the reduction of path model linkages, resulting in model parsimoniousness (Sarstedt et al., 2019).

The conceptual framework has three variables that may mediate three causal relationships. The causal relationship between two variables can be further explored by studying mediating effects (Hair et al., 2017). The mediating effects are tested in terms of direct, indirect, and total effects. The mediating results contribute implications for theory building (Zhao et al., 2010).

\section{RESULTS}

The survey was distributed to employees working in the aviation industry of Vietnam. 249 answer sheets were collected from respondents. 193 valid responses were selected and 56 were omit- ted due to missing data and low variation. Table 1 summarizes the valid respondents' demographic information.

Construct reliability and convergent validity were assessed by using the thresholds proposed by Hair et al. (2017) (Table A1). To satisfy all thresholds, some items were selected because their outer loadings were greater than 0.7 . Table A1 shows that all construct thresholds were in the accepted range according to Cronbach's alpha, rho-A, composite reliability (CR), and average variance extracted (AVE) values.

According to Wetzels et al. (2009), $R$-squared values are classified into three ranges that reflect the quality of a structural model analyzed using the PLS approach, namely small, medium and larger effects (below 0.02, in the range of 0.13 to 0.26 , and above 0.26 , respectively). It shows that the structural model had a more significant effect with an R-squared value of 0.583 for job performance (Table A1), supporting the model's predictive power.

The Heterotrait-Monotrait (HTMT) ratio and the Fornell-Larcker criterion were used to assess discriminant validity. Table 2 shows that HTMT ratios were below 0.9 for all pairs of constructs, meeting the benchmark proposed by Hair et al. (2017).

Table 3 demonstrates that the square root of AVE for each latent construct was higher than the off-diagonal correlation, thus achieving adequate discriminant validity (Hair et al., 2017). Hence, all latent constructs had good reliability and convergent validity.

Table 4 and Figure 2 demonstrate that all hypotheses were supported, showing positive relationships

Table 1. Demographics of the respondents

\begin{tabular}{|c|c|c|c|}
\hline Demographics & Categories & Respondents & Percentage (\%) \\
\hline \multirow{2}{*}{ Gender } & Male & 116 & 60.1 \\
\hline & Female & 77 & 39.9 \\
\hline \multirow{3}{*}{ Age } & Below 31 years old & 87 & 45.08 \\
\hline & From 31 to 40 years old & 27 & 13.99 \\
\hline & Above 40 years old & 79 & 40.93 \\
\hline \multirow{3}{*}{ Education } & Undergraduates & 143 & 74.09 \\
\hline & Post-graduates & 20 & 10.36 \\
\hline & Others & 30 & 15.55 \\
\hline \multicolumn{2}{|l|}{ Total } & 193 & 100 \\
\hline
\end{tabular}


Table 2. Discriminant validity (Heterotrait-Monotrait ratios)

Source: Authors' elaboration.

\begin{tabular}{|c|c|c|c|c|c|c|c|}
\hline \multirow{2}{*}{\multicolumn{2}{|c|}{ Constructs }} & \multicolumn{6}{|c|}{ Heterotrait-Monotrait Ratio (HTMT) } \\
\hline & & 1 & 2 & 3 & 4 & 5 & 6 \\
\hline 1 & Employee engagement & \multicolumn{2}{|c|}{ Criteria $<0.9$} & & & & \\
\hline 2 & Internal social media & 0.689 & & & & & \\
\hline 3 & Job performance & 0.828 & 0.569 & & & & \\
\hline 4 & Life satisfaction & 0.751 & 0.57 & 0.726 & & & \\
\hline 5 & Organizational identification & 0.85 & 0.68 & 0.679 & 0.636 & & \\
\hline 6 & Perceived organizational transparency & 0.682 & 0.566 & 0.665 & 0.633 & 0.603 & \\
\hline
\end{tabular}

Table 3. Discriminant validity (Fornell-Larcker Criterion)

Source: Authors' elaboration.

\begin{tabular}{|c|c|c|c|c|c|c|c|}
\hline \multirow{2}{*}{\multicolumn{2}{|c|}{ Constructs }} & \multicolumn{6}{|c|}{ Fornell-Larcker Criterion } \\
\hline & & 1 & 2 & 3 & 4 & 5 & 6 \\
\hline 1 & Employee engagement & 0.779 & & & & & \\
\hline 2 & Internal social media & 0.65 & 0.89 & & & & \\
\hline 3 & Job performance & 0.747 & 0.515 & 0.802 & & & \\
\hline 4 & Life satisfaction & 0.659 & 0.494 & 0.612 & 0.84 & & \\
\hline 5 & Organizational identification & 0.786 & 0.631 & 0.599 & 0.548 & 0.85 & \\
\hline 6 & Perceived organizational transparency & 0.617 & 0.519 & 0.571 & 0.536 & 0.531 & 0.836 \\
\hline
\end{tabular}

$(p \leq 0.05)$. ISM significantly impacted POT, employee engagement, and organizational identification $(\beta=0.519 ; \beta=0.184$ and $\beta=0.631$, respectively, i.e., $H 1, H 2$, and $H 3$ were supported). POT and organizational identification significantly impacted employee engagement $(\beta=0.231$ and $\beta=0.547$, respectively; i.e., $H 4$ and $H 5$ were supported). Employee engagement significantly impacted life satisfaction and job performance $(\beta=0.659$ and $\beta=0.606$, respectively; i.e., $H 6$ and $H 7$ were supported). Life satisfaction significantly impacted job performance ( $\beta=0.213$; i.e., $H 8$ was supported).
Table 5 reveals the results of mediation testing with three potential mediators. POT and organizational identification had a complementary mediation on the positive linkage between ISM and employee engagement. Life satisfaction had a complementary mediation on the positive linkage between employee engagement and job performance. Zhao et al. (2010) introduced different types of mediation, each of which had significant implications for theory building. Complementary mediation implies an incomplete theoretical framework. The identified mediator should be consistent with the

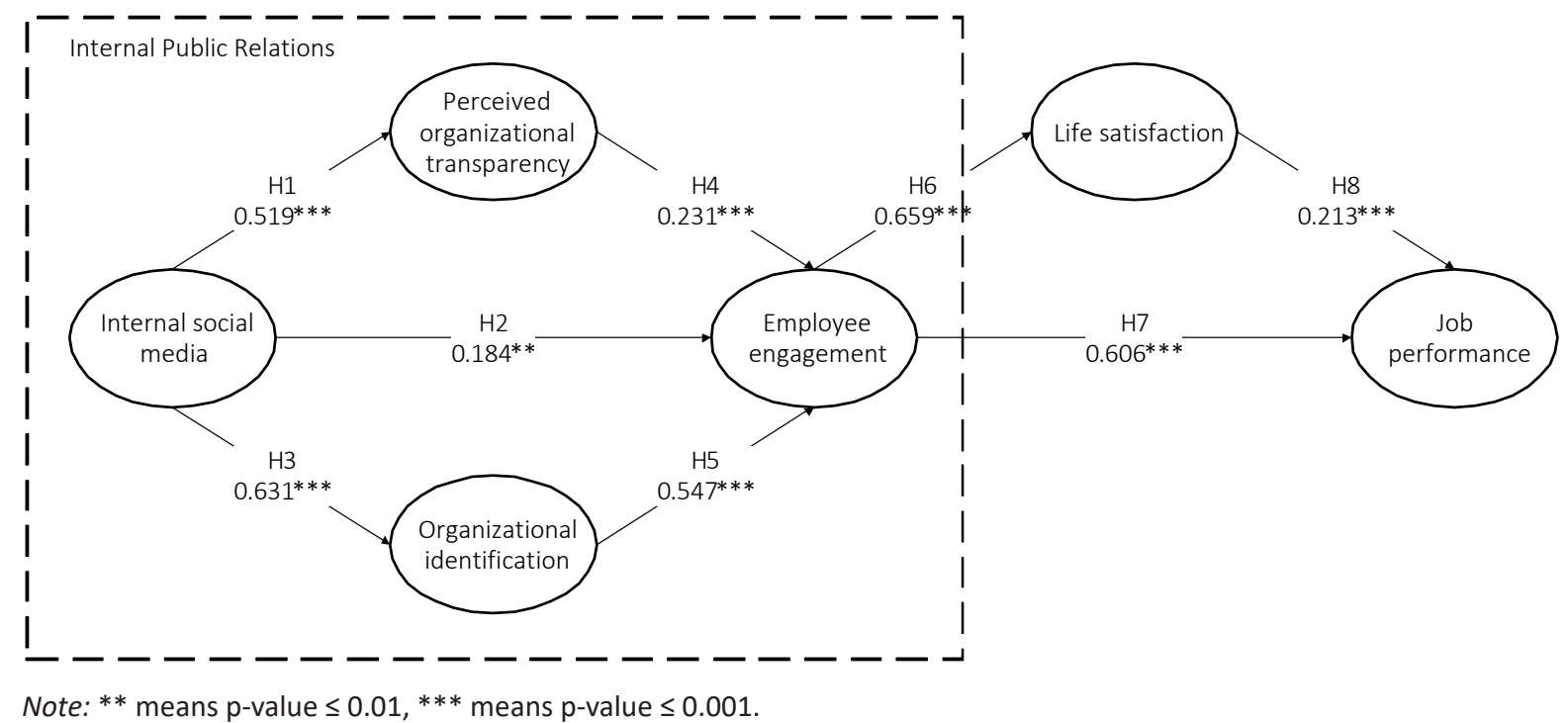

Figure 2. Results of hypothesis testing 
Table 4. Results of hypothesis testing

Source: Authors' elaboration.

\begin{tabular}{|c|c|c|c|}
\hline Hypotheses & Relationships & Estimates & Results \\
\hline $\mathrm{H} 1$ & $\mathrm{ISM} \rightarrow \mathrm{POT}$ & $0.519 * * *$ & Supported \\
\hline $\mathrm{H} 2$ & $\mathrm{ISM} \rightarrow \mathrm{EE}$ & $0.184^{* *}$ & Supported \\
\hline $\mathrm{H} 3$ & $\mathrm{ISM} \rightarrow \mathrm{OI}$ & $0.631 * * *$ & Supported \\
\hline $\mathrm{H} 4$ & $\mathrm{POT} \rightarrow \mathrm{EE}$ & $0.231^{* * *}$ & Supported \\
\hline $\mathrm{H} 5$ & $\mathrm{OI} \rightarrow \mathrm{EE}$ & $0.547 * * *$ & Supported \\
\hline $\mathrm{H} 6$ & $\mathrm{EE} \rightarrow \mathrm{LS}$ & $0.659 * * *$ & Supported \\
\hline $\mathrm{H} 7$ & $\mathrm{EE} \rightarrow \mathrm{JP}$ & $0.606 * * *$ & Supported \\
\hline $\mathrm{H} 8$ & $\mathrm{LS} \rightarrow \mathrm{JP}$ & $0.213^{* * *}$ & Supported \\
\hline
\end{tabular}

Note: ${ }^{* *}$ means $p$-value $\leq 0.01, * * *$ means $p$-value $\leq 0.001$.

Table 5. Results of mediating effects

Source: Authors' elaboration.

\begin{tabular}{|c|c|c|c|c|c|c|}
\hline $\begin{array}{c}\text { Independent } \\
\text { variables }\end{array}$ & Mediators & $\begin{array}{c}\text { Dependent } \\
\text { variables }\end{array}$ & Direct effects & Indirect effects & Total effects & Mediation \\
\hline ISM & POT & $\mathrm{EE}$ & $0.184^{* *}$ & $0.12^{* * *}$ & $0.65^{* * *}$ & Complementary \\
\hline ISM & Ol & $\mathrm{EE}$ & $0.184 * *$ & $0.345^{* * *}$ & $0.65 * * *$ & Complementary \\
\hline $\mathrm{EE}$ & LS & $J P$ & $0.606 * * *$ & $0.14^{* * *}$ & $0.747 * * *$ & Complimentary \\
\hline
\end{tabular}

Note: ${ }^{* *}$ means $p$-value $\leq 0.01, * * *$ means $p$-value $\leq 0.001$

hypothesized theoretical framework and could be eliminated to support a direct relationship.

\section{DISCUSSION}

All five hypotheses generated regarding ISM, POT, organizational identification, and employee engagement in the conceptual framework are supported by significant evidence of positive impacts. Two mediating effects among these four constructs were recorded as complimentary mediation.

The structural model of Men et al. (2020) was connected to job performance via employee engagement to generate the hybrid model in this study. On the one hand, it is in line with the previous results on employee engagement as a positive driver of job performance (Christian et al., 2011; Anitha, 2014; Rich et al., 2010). On the other hand, this hybrid model can contribute new drivers (e.g., ISM, POT, organizational identification) to explore the antecedents of employee engagement and thus enhance job performance.

The triangular relationship among employee engagement, life satisfaction, and job performance has not been explored thoroughly and has only been partially investigated in previous studies. The significantly positive impacts of employee engagement on life satisfaction that was identified are consistent with the findings of Mache et al. (2014). Specifically, the incredibly positive linkage between life satisfaction and job performance is in line with the results of Talukder et al. (2018). Moreover, this study provided evidence that life satisfaction generates complementary mediation intervening in the positive linkage between employee engagement and job performance. In terms of implications for theory building, this paper thus provides a deeper understanding of the triangular relationships among employee engagement, life satisfaction, and job performance.

This paper is beneficial for specialists working in internal public relations and organizational effectiveness in the aviation industry in Vietnam. By maximizing the presence of social media inside the company, an organization can improve organizational effectiveness as well as individual employees' personal development and lives. That said, ISM is used to raise organizational transparency and images among employees. To accomplish this, an organization must concern technological investments, interface design, and time resources needed for ISM. After ISM is developed, the organization should ensure that almost all employees can use it properly by encouraging them to share their views, experi- 
ences, and expertise. The organization should also engage management to interact with posts and have private chats with employees (i.e., oneon-one mentorship). It can enhance employees' sense of ownership toward their organization and thereby improve day-to-day organizational attachment. Over time, employees will develop an attitude of devotion to their jobs and the organization, increasing job performance in general. They will ultimately achieve self-satisfaction in their professional and personal lives. Companies can use internal public relations to improve their business performance and organizational survival as intangible assets.

The study adds to the existing body of knowledge on employee engagement. The integrated model was created to demonstrate the caus- es and effects of employee engagement in the practice of internal public relations. Adoption of ISM, POT, and organizational identification can be new antecedents of employee engagement. In turn, employee engagement generates life satisfaction and job performance as consequences. This integrative model offers a new explanation of employee engagement as an alternative to the models developed by Saks (2006, 2019). The study also provides an exception-al theoretical contribution in observing employee engagement as the second-order construct with two first-order constructs (job engagement and organizational engagement) in the hy-brid model. This offers a significant fulfillment of the research gap from Saks (2019) to distinguish between job engagement and organizational engagement.

\section{CONCLUSION}

It was the first study exploring the sequencing mechanisms to generate employee engagement and life satisfaction from ISM. The new point from this study was the use of the hierarchical component model with a multidimensional construct (i.e., employee engagement was measured by job engagement and organizational engagement). The study provided empirical evidence supporting internal public relations to enhance life satisfaction and improve job performance. The current study expands the general model showing antecedents and consequences of employee engagement, significantly block concepts related to internal public relations as new antecedents of employee engagement. The organization may encourage its employees to use ISM to understand organizational transparency and images. Gradually, employees feel engaged with their job and the organization and make valuable devotion in their work. Ultimately, the organization may benefit from its employees' job performance and work-life balance. Research replication and approaching multi-source respondents would expand this study. Applying quasi-experiments to explore internal public relations would be a new direction for further research.

\section{AUTHOR CONTRIBUTIONS}

Conceptualization: Phuong Nguyen.

Funding acquisition: Phuong Nguyen, Hoa Quynh Tran.

Data curation: Luan The Vuong.

Formal analysis: Han Nu Ngoc Ton.

Methodology: Phuong Nguyen.

Project administration: Hoa Quynh Tran.

Validation: Phuong Nguyen, Han Nu Ngoc Ton.

Visualization: Hoa Quynh Tran.

Writing-original draft: Han Nu Ngoc Ton.

Writing-review and editing: Phuong Nguyen, Han Nu Ngoc Ton. 


\section{ACKNOWLEDGMENT}

This study is funded by Vietnam National University of Ho Chi Minh City (VNU-HCMC) under grant number B2020-28-02.

\section{REFERENCES}

1. Anitha, J. (2014). Determinants of employee engagement and their impact on employee performance. International Journal of Productivity and Performance Management, 63(3), 308-323. https://doi.org/10.1108/ IJPPM-01-2013-0008

2. Ashforth, B. E., Harrison, S. H., \& Corley, K. G. (2008). Identification in Organizations: An Examination of Four Fundamental Questions. Journal of Management, 34(3), 325-374. https://doi. org/10.1177/0149206308316059

3. Berggren, E., \& Bernshteyn, R. (2007). Organizational transparency drives company performance. Journal of Management Development, 26(5), 411-417. https://doi. org/10.1108/02621710710748248

4. Borman, W. C., \& Motowidlo, S. J. (1993). Expanding the criterion domain to include elements of contextual performance. In N. Schmitt \& W. C. Borman (Eds.), Personnel selection in organizations (pp. 71-98). San Francisco, CA: Jossey-Bass.

5. Borman, W. C., \& Motowidlo, S. J. (1997). Task Performance and Contextual Performance: The Meaning for Personnel Selection Research. Human Performance, 10(2), 99-109. https://doi. org/10.1207/s15327043hup1002_3

6. Christian, M. S., Garza, A. S., \& Slaughter, J. E. (2011). Work Engagement: A Quantitative Review and Test of its Relations With Task and Contextual Performance. Personnel Psychology, 64(1), 89-136. https://doi.org/10.1111/j.17446570.2010.01203.x

7. Cropanzano, R., \& Mitchell, M. S. (2005). Social Exchange Theory: An Interdisciplinary
Review. Journal of Management, 31(6), 874-900. https://doi. org/10.1177/0149206305279602

8. Cropanzano, R., Anthony, E. L., Daniels, S. R., \& Hall, A. V. (2017). Social Exchange Theory: A Critical Review with Theoretical Remedies. Academy of Management Annals, 11(1), 479-516. https://doi.org/10.5465/ annals.2015.0099

9. Demerouti, E., \& Cropanzano, R. (2010). From thought to action: Employee work engagement and job performance. In M. P. Leiter \& A. B. Bakker (Eds.), Work Engagement: A Handbook of Essential Theory and Research (pp. 147-163). New York: Psychology Press.

10. Demerouti, E., Bakker, A. B., Nachreiner, F., \& Schaufeli, W. B. (2001). The job demandsresources model of burnout. Journal of Applied Psychology, 86(3), 499-512. https://doi. org/10.1037/0021-9010.86.3.499

11. Edwards, J. R. (2001). Multidimensional Constructs in Organizational Behavior Research: An Integrative Analytical Framework. Organizational Research Methods, 4(2), 144-192. https://doi. org/10.1177/109442810142004

12. Ewing, M., Men, L. R., \& O’Neil, J. (2019). Using Social Media to Engage Employees: Insights from Internal Communication Managers. International Journal of Strategic Communication, 13(2), 110-132. https://doi.org/10.1080/1 553118X.2019.1575830

13. Freberg, K. (2019). Social Media and Emerging Media: Theoretical Foundations. In B. R. Brunner (Ed.), Public Relations Theory: Application and Understanding ( $1^{\text {st }}$ ed.). John Wiley \& Sons.
14. Hair, J. F., Hult, G. T. M., Ringle, C. M., \& Sarstedt, M. (2017). A primer on partial least squares structural equation modeling (PLS$S E M)\left(2^{\text {nd }}\right.$ ed.). Thousand Oaks, CA: SAGE Publication, Inc.

15. Halbesleben, J. R. B. (2010). A meta-analysis of work engagement: Relationships with burnout, demands, resources, and consequences. In M. P. Leiter \& A. B. Bakker (Eds.), Work Engagement: A Handbook of Essential Theory and Research (pp. 102-131). New York: Psychology Press.

16. He, H., Zhu, W., \& Zheng, X. (2014). Procedural Justice and Employee Engagement: Roles of Organizational Identification and Moral Identity Centrality. Journal of Business Ethics, 122(4), 681-695. https://doi.org/10.1007/s10551013-1774-3

17. Henseler, J., Hubona, G., \& Ray, P. A. (2016). Using PLS path modeling in new technology research: updated guidelines. Industrial Management \& Data Systems, 116(1), 2-20. https://doi. org/10.1108/IMDS-09-2015-0382

18. Jiang, H., \& Men, R. L. (2017). Creating an Engaged Workforce: The Impact of Authentic Leadership, Transparent Organizational Communication, and Work-Life Enrichment. Communication Research, 44(2), 225-243. https://doi. org/10.1177/0093650215613137

19. Johnson, R. E., Rosen, C. C., \& Chang, C.-H. (2011). To Aggregate or Not to Aggregate: Steps for Developing and Validating Higher-Order Multidimensional Constructs. Journal of Business and Psychology, 26(3), 241-248. https://doi. org/10.1007/s10869-011-9238-1 
20. Juhdi, N., Pa’wan, F., \& Hansaram, R. M. K. (2013). HR practices and turnover intention: the mediating roles of organizational commitment and organizational engagement in a selected region in Malaysia. The International Journal of Human Resource Management, 24(15), 3002-3019. https://doi.org/10.1080/09585192. 2013.763841

21. Kahn, W. A. (1990). Psychological Conditions of Personal Engagement and Disengagement at Work. Academy of Management Journal, 33(4), 692-724. https://doi. org/10.5465/256287

22. Kennan, W. R., \& Hazleton, V. (2006). Internal Public Relations, Social Capital, and the Role of Effective Organizational Communication. In C. H. Botan \& V. Hazleton (Eds.), Public Relations Theory II ( $1^{\text {st }}$ ed.) (pp. 311-338). Routledge.

23. Leiter, M. P., \& Bakker, A. B. (2010). Work engagement: Introduction. In A. B. Bakker \& M. P. Leiter (Eds.), Work Engagement: A Handbook of Essential Theory and Research (pp. 1-9). New York: Psychology Press.

24. Leonardi, P. M., Huysman, M., \& Steinfield, C. (2013). Enterprise Social Media: Definition, History, and Prospects for the Study of Social Technologies in Organizations. Journal of Computer-Mediated Communication, 19(1), 1-19. https://doi.org/10.1111/jcc4.12029

25. Linhart, S. (2011, July 18). Job one: Keeping employees happy and engaged. PRWeek. Retrieved January 18, 2021, from https://www.prweek.com/ article/1263788/job-one-keepingemployees-happy-engaged

26. Mache, S., Vitzthum, K., Klapp, B. F., \& Danzer, G. (2014). Surgeons' work engagement: Influencing factors and relations to job and life satisfaction. The Surgeon, 12(4), 181-190. https://doi.org/10.1016/j. surge.2013.11.015

27. McCorkindale, T., \& Distaso, M. W. (2014). The State of Social Media Research: Where Are We Now, Where We Were and What
It Means for Public Relations. Research Journal of the Institute for Public Relations, 1(1), 1-17. Retrieved from http://www.instituteforpr.org/wp-content/uploads/ TinaMarciaWES.pdf

28. Men, L. R., \& Tsai, W.-H. S. (2013). Beyond liking or following: Understanding public engagement on social networking sites in China. Public Relations Review, 39(1), 13-22. https://doi. org/10.1016/j.pubrev.2012.09.013

29. Men, L. R., O’Neil, J., \& Ewing, M. (2020). Examining the effects of internal social media usage on employee engagement. Public Relations Review, 46(2), 101880. https://doi.org/10.1016/j.pubrev.2020.101880

30. Miller, V. D., Allen, M., Casey, M. K., \& Johnson, J. R. (2000). Reconsidering the Organizational Identification Questionnaire. Management Communication Quarterly, 13(4), 626-658. https://doi. org/10.1177/0893318900134003

31. Muntinga, D. G., Moorman, M., \& Smit, E. G. (2011). Introducing COBRAs. International Journal of Advertising, 30(1), 13-46. https:// doi.org/10.2501/IJA-30-1-013-046

32. Parry, E., \& Solidoro, A. (2013). Social Media as a Mechanism for Engagement. In Social Media in Human Resources Management (pp. 121-141). Emerald Group Publishing Limited. https:// doi.org/10.1108/S1877 6361(2013)0000012010

33. Polites, G. L., Roberts, N., \& Thatcher, J. (2012). Conceptualizing models using multidimensional constructs: a review and guidelines for their use. European Journal of Information Systems, 21(1), 22-48. https://doi. org/10.1057/ejis.2011.10

34. Rawlins, B. (2008). Measuring the Relationship Between Organizational Transparency and Employee Trust. Public Relations Journal, 2(2), 1-21. Retrieved from https://prjournal.instituteforpr. org/wp-content/uploads/Measuring-the-relationship.pdf
35. Rich, B. L., Lepine, J. A., \& Crawford, E. R. (2010). Job Engagement: Antecedents and Effects on Job Performance. Academy of Management Journal, 53(3), 617-635. https://doi. org/10.5465/amj.2010.51468988

36. Saks, A. M. (2006). Antecedents and consequences of employee engagement. Journal of Managerial Psychology, 21(7), 600-619. https://doi. org/10.1108/02683940610690169

37. Saks, A. M. (2019). Antecedents and consequences of employee engagement revisited. Journal of Organizational Effectiveness: People and Performance, 6(1), 19-38. https://doi.org/10.1108/JOEPP-06-2018-0034

38. Sarstedt, M., Hair, J. F., Cheah, J.-H., Becker, J.-M., \& Ringle, C. M. (2019). How to Specify, Estimate, and Validate HigherOrder Constructs in PLS-SEM. Australasian Marketing Journal, 27(3), 197-211. https://doi. org/10.1016/j.ausmj.2019.05.003

39. Schaufeli, W. B., \& Bakker, A. B. (2010). Defining and measuring work engagement: Bringing clarity to the concept. In A. B. Bakker \& M. P. Leiter (Eds.), Work Engagement: A Handbook of Essential Theory and Research (pp. 10-24). New York: Psychology Press.

40. Smidts, A., Pruyn, A. T. H., \& Van Riel, C. B. M. (2001). The Impact of Employee Communication and Perceived External Prestige on Organizational Identification. Academy of Management Journal, 44(5), 1051-1062. https://doi. org/10.5465/3069448

41. Talukder, A. K. M., Vickers, M., \& Khan, A. (2018). Supervisor support and work-life balance. Personnel Review, 47(3), 727-744. https://doi.org/10.1108/PR-122016-0314

42. Taurasi, L. (2015, July 6). 7 Ways to Use Social Media for Employee Communications. CareAtWork. Retrieved January 18, 2021, from https://workplace.care.com/7ways-to-use-social-media-foremployee-communications 
43. Wang, Y., \& Kobsa, A. (2009). Privacy in Online Social Networking at Workplace. 2009 International Conference on Computational Science and Engineering, 975-978. https://doi. org/10.1109/CSE.2009.438

44. Weber, M. S., \& Shi, W. (2016). Enterprise Social Media. In C. R. Scott, L. Lewis, J. R. Barker, J. Keyton, T. Kuhn, \& P. K. Turner (Eds.), The International Encyclopedia of Organizational Communication (pp. 1-9). https:// doi.org/10.1002/9781118955567. wbieoc 072
45. Wetzels, M., Odekerken-Schröder, G., \& Van Oppen, C. (2009). Using PLS Path Modeling for Assessing Hierarchical Construct Models: Guidelines and Empirical Illustration. MIS Quarterly, 33(1), 177-195. https://doi. org/10.2307/20650284

46. Xanthopoulou, D., Baker, A. B., Heuven, E., Demerouti, E., \& Schaufeli, W. B. (2008). Working in the sky: A diary study on work engagement among flight attendants. Journal of Occupational Health Psychology, 13(4), 345-356. https://doi. org/10.1037/1076-8998.13.4.345
47. Xanthopoulou, D., Bakker, A. B., Demerouti, E., \& Schaufeli, W. B. (2009). Work engagement and financial returns: A diary study on the role of job and personal resources. Journal of Occupational and Organizational Psychology, 82(1), 183-200. https://doi. org/10.1348/096317908X285633

48. Zhao, X., Lynch, J. G., \& Chen, Q. (2010). Reconsidering Baron and Kenny: Myths and Truths about Mediation Analysis. Journal of Consumer Research, 37(2), 197-206. https://doi. org/10.1086/651257

\section{APPENDIX A}

Table A1. Reliability and convergent validity of the latent constructs

Source: Authors' elaboration.

\begin{tabular}{|c|c|c|c|c|c|c|c|c|}
\hline Constructs & Mean & SD & $\begin{array}{l}\text { Factor } \\
\text { Loading }\end{array}$ & Cronbach's Alpha & rho_A & CR & AVE & $R$-Squared \\
\hline \multicolumn{4}{|l|}{ Threshold } & $\geq 0.7$ & $\geq 0.7$ & $\geq 0.7$ & $\geq 0.5$ & \\
\hline \multicolumn{4}{|c|}{ Internal social media } & 0.934 & 0.938 & 0.95 & 0.792 & \\
\hline SM1 & 4.567 & 0.727 & 0.838 & & & & & \\
\hline SM2 & 4.513 & 0.747 & 0.896 & & & & & \\
\hline SM3 & 4.312 & 0.943 & 0.894 & & & & & \\
\hline SM4 & 4.396 & 0.907 & 0.913 & & & & & \\
\hline SM5 & 4.454 & 0.81 & 0.906 & & & & & \\
\hline \multicolumn{4}{|c|}{ Perceived organizational transparency } & 0.855 & 0.878 & 0.902 & 0.699 & 0.269 \\
\hline POT1 & 4.325 & 0.813 & 0.895 & & & & & \\
\hline POT2 & 4.412 & 0.736 & 0.905 & & & & & \\
\hline РOT3 & 4.533 & 0.67 & 0.784 & & & & & \\
\hline POT4 & 4.463 & 0.735 & 0.749 & & & & & \\
\hline \multicolumn{4}{|c|}{ Organizational identification } & 0.904 & 0.906 & 0.929 & 0.723 & 0.398 \\
\hline OI1 & 4.596 & 0.625 & 0.856 & & & & & \\
\hline 012 & 4.575 & 0.679 & 0.86 & & & & & \\
\hline $\mathrm{OI3}$ & 4.517 & 0.664 & 0.883 & & & & & \\
\hline $\mathrm{Ol4}$ & 4.404 & 0.774 & 0.83 & & & & & \\
\hline $\mathrm{Ol5}$ & 4.529 & 0.689 & 0.82 & & & & & \\
\hline \multicolumn{4}{|c|}{ Employee engagement } & 0.941 & 0.942 & 0.949 & 0.606 & 0.693 \\
\hline \multicolumn{4}{|c|}{ Job engagement } & 0.928 & 0.93 & 0.941 & 0.668 & 0.945 \\
\hline EE1 & 4.546 & 0.675 & 0.785 & & & & & \\
\hline EE2 & 4.721 & 0.509 & 0.814 & & & & & \\
\hline EE3 & 4.683 & 0.57 & 0.865 & & & & & \\
\hline EE4 & 4.708 & 0.561 & 0.789 & & & & & \\
\hline EE5 & 4.596 & 0.664 & 0.844 & & & & & \\
\hline EE6 & 4.588 & 0.599 & 0.828 & & & & & \\
\hline EE7 & 4.529 & 0.683 & 0.874 & & & & & \\
\hline EE10 & 4.404 & 0.856 & 0.728 & & & & & \\
\hline \multicolumn{4}{|c|}{ Organizational engagement } & 0.867 & 0.867 & 0.91 & 0.717 & 0.783 \\
\hline EE11 & 4.408 & 0.764 & 0.77 & & & & & \\
\hline EE14 & 4.229 & 0.737 & 0.889 & & & & & \\
\hline EE15 & 4.225 & 0.758 & 0.89 & & & & & \\
\hline
\end{tabular}


Problems and Perspectives in Management, Volume 19, Issue 3, 2021

Table A1 (cont.). Reliability and convergent validity of the latent constructs

\begin{tabular}{|c|c|c|c|c|c|c|c|c|}
\hline Constructs & Mean & SD & $\begin{array}{l}\text { Factor } \\
\text { Loading }\end{array}$ & Cronbach's Alpha & rho_A & CR & AVE & $R$-Squared \\
\hline EE16 & 4.567 & 0.616 & 0.831 & & & & & \\
\hline \multicolumn{4}{|c|}{ Life satisfaction } & 0.792 & 0.813 & 0.877 & 0.705 & 0.434 \\
\hline LS1 & 4.233 & 0.849 & 0.901 & & & & & \\
\hline LS3 & 4.375 & 0.72 & 0.78 & & & & & \\
\hline LS5 & 4.183 & 1.103 & 0.835 & & & & & \\
\hline \multicolumn{4}{|c|}{ Job performance } & 0.86 & 0.871 & 0.9 & 0.644 & 0.583 \\
\hline JP1 & 4.763 & 0.506 & 0.72 & & & & & \\
\hline$J P 2$ & 4.779 & 0.444 & 0.726 & & & & & \\
\hline JP3 & 4.517 & 0.769 & 0.853 & & & & & \\
\hline JP4 & 4.425 & 0.828 & 0.817 & & & & & \\
\hline JP5 & 4.583 & 0.684 & 0.882 & & & & & \\
\hline
\end{tabular}

Notes: * means second-order latent constructs, CR = Composite Reliability, AVE = Average Variance Extracted. 